\title{
Development of an Isotope Dilution Liquid Chromatography/Tandem Mass Spectrometry Detection Method for DNA Adducts of Selected Aromatic Amines
}

\author{
Jay C. Means, Phil D. Olsen, and Elke Schoffers \\ Department of Chemistry, Western Michigan University, Kalamazoo, Michigan, USA
}

\begin{abstract}
Polycyclic aromatic amines (arylamines) are a class of chemical carcinogens that are prevalent in environmental and industrial settings. They are metabolically activated to covalently bond to DNA, forming mutagenic adducts. In order to study the mechanisms of their toxicity, sensitive and selective quantitative LC/MS/MS detection methods were developed to measure the $\mathrm{N}$-(adenin-8-yl)-benzidine adduct and $\mathrm{N}$-(adenin-8-yl)-2-aminofluorene in total DNA extract samples. A novel synthetic method using a palladium catalyst was previously developed to prepare authentic and deuterated arylamine-adenine adducts to serve as standards. These standards were then used to develop an HPLC electrospray ionization tandem mass spectrometry, isotope dilution method. Sample detection limits in DNA samples were $22 \mathrm{pg}$ on-column and $51 \mathrm{pg}$ on-column for the $\mathrm{N}$-(adenin-8-yl)-benzidine- and $\mathrm{N}$-(adenin8-yl)-2-aminofluorene-adenine adducts, respectively. This method has applications for the study of DNA adduct formation as a biological marker of exposure to carcinogens and for environmental and workplace monitoring of these aromatic amines. (J Am Soc Mass Spectrom 2003, 14, 1057-1066) (C 2003 American Society for Mass Spectrometry
\end{abstract}

$\mathrm{N}$ itrogen-containing polycyclic aromatic hydrocarbons (PAHs), including primary aromatic amines, occur intermittently with other PAHs that are ubiquitous in the environment and are prevalent in coal and its refined products [1]. They have been used extensively in the dye, rubber, and plastics industries, and some can be found in tobacco smoke, or in cooked food [2,3]. Benzidine is used in the synthesis of many types of dyes and is produced at a rate of $\sim 10$ million pounds per year, almost entirely as captive use [4]. Benzidine has been classified as a group A human carcinogen by the Agency for Toxic substance and Disease Registry (ATSDR) [5, 6] and the US Environmental Protection Agency (EPA) lists benzidine as a hazardous air pollutant in the Clean Air Act of 1990 [6]. Benzidine is primarily used in the production of dyes for the leather, textile, and paper industries [5]. Health effects occur with both chronic and acute exposure, and range from dermal sensitivity to bladder cancer $[4,5]$. 2-Aminofluorene has also been widely studied in laboratories, although not as extensively as benzidine with regard to human exposures.

Arylamines are activated in vivo by a variety of

Published online July 28, 2003

Address reprint requests to Dr. J. C. Means, Department of Chemistry, Western Michigan University, 3446 Wood Hall, Kalamazoo, MI 49008-5413, USA. E-mail: jay.means@wmich.edu enzymes that convert the amine functionality into a reactive nitrenium ion that has been implicated in the covalent bonding to the nucleophilic sites of DNA to form adducts [2,3]. If these adducts are not repaired they can cause base substitutions or deletions that can lead to cancer [4]. The effects include formation of DNA adducts and protein adducts, increased rates of sister chromatid exchanges, lung, bladder and skin cancer, transplacental transfer, premature ovarian failure, and activation of the aromatic hydrocarbon receptors (AhR) [7-14]. Numerous publications have shown that the metabolic products of both 2-aminofluorene and benzidine are mutagenic [15-21].

The detection of DNA adducts in tissues is an analytical challenge. Their formation is rare and the isolation of tissue DNA as a sample matrix dictates that most samples will have low concentrations. Yet because carcinogens have no threshold of safety for exposure and exposure to a few molecules at the cellular level may lead to mutational events at critical loci that can ultimately be expressed as tumor formation which may be potentially fatal, it is important to detect them at very low frequencies ( 1 adduct in $10^{7}$ normal nucleotides) [22]. Not only do they need to be detected at low levels, but also their rates of formation and repair need to be studied, and the complete mechanism of their carcinogenicity understood.

The detection of DNA adducts by high performance 
liquid chromatography (HPLC) electrospray ionization (ESI) tandem mass spectrometry (MS/MS) offers several advantages that other methods do not possess [22]. This method offers the advantages of not requiring radioactive compounds, or hard to obtain antibodies. It also provides specific qualitative information in the form of molecular weights and characteristic fragmentation. Aside from serving as a useful tool to study adduct formation and the mechanisms of tumor initiation, this method also measures direct evidence of primary damage to DNA that measuring the tissue concentration of the parent arylamines does not do. Measuring DNA adducts themselves is thought to be a more precise and reliable way to determine the risks from carcinogen exposure [23, 24]. Consequently the use of DNA adducts as biomarkers for risk assessment and environmental monitoring is increasing [25].

In this paper we report the development of a quantitative HPLC/ESI/MS/MS isotope dilution method to detect the presence of $\mathrm{N}$-(adenin-8-yl)-benzidine adducts and $\mathrm{N}$-(adenin-8-yl)-2-aminofluorene in total DNA extracts from tissues. The ultimate goal of being able to quantify these DNA adducts at physiologically significant level of 1 adduct in $10^{7}$ normal nucleotides has been achieved.

\section{Experimental}

\section{Reagents}

The per-deutero- and non-labeled N-(adenin-8-yl)-2aminofluorene and $\mathrm{N}$-(adenin-8-yl)-benzidine were prepared using our new method of palladium catalysis [26]. The specifics of the synthesis for the per-deutero compounds are to be published in a separate manuscript. C-18 Sep-Pak cartridges were purchased from Waters (Milford, MA). The arylamines used in these syntheses were $99+\%$ pure reagents from Sigma (St. Louis, MO). All solvents used for LC/MS and LC/ MS/MS analysis were HPLC grade from Fisher Scientific (Itasca, IL).

\section{HPLC}

HPLC separation of aryl amine adducts was performed on a Zorbax SB-CN reverse-phase column $(250 \times 4.6$ $\mathrm{mm}, 5 \mu \mathrm{m}$ ) (MAC-MOD Analytical, Inc., Chadds Ford, PA) using a Waters 2696 multi-solvent delivery system equipped with a Waters 2487 dual wavelength UV detector and an auto-injector. A flow rate of $1 \mathrm{ml} / \mathrm{min}$. used with a 1:1 split between the UV detector and electrospray ionization (ESI) interface. Both mobile phases (Solvent $\mathrm{A}=$ ultrapure water; Solvent $\mathrm{B}=$ acetonitrile) contained $0.2 \%$ formic acid to assist in ESI positive ionization. A linear gradient program was run as follows: $0 \mathrm{~min}, 100 \% \mathrm{~A} ; 5 \mathrm{~min}, 100 \% \mathrm{~A} ; 25 \mathrm{~min}, 100 \%$ B: $30 \mathrm{~min}, 100 \%$ B; $35 \mathrm{~min}, 100 \%$ A; $40 \mathrm{~min}, 100 \% \mathrm{~A}$.

\section{Mass Spectrometry}

Mass spectrometry was performed on a Waters-Micromass (Wythenshawe, UK) Quattro II triple-quadrupole mass spectrometer using the ESI source in a Z-spray configuration operating in the positive ion detection mode. Tuning of the ionization source and optimization of the MS/MS parameters were carried out using non-labeled N-(adenin-8-yl)-2-aminofluorene and $\mathrm{N}$-(adenin-8-yl)-benzidine adducts, respectively. Standards $(5 \mathrm{ng} / \mu \mathrm{L})$ were prepared in methanol containing $0.2 \%$ formic acid and infused into the mass spectrometer with a Harvard syringe pump at a flow rate 10 $\mu \mathrm{L} / \mathrm{min}$. Full scan mass spectra of each arylamine adduct standard were collected over a mass range of $\mathrm{m} / \mathrm{z} 110$ to 400 at a scan rate of 1.2 scans per sec. and an intra-scan time of $0.2 \mathrm{~ms}$. After the ESI interface nitrogen gas $(99.999 \%$ pure) flow for drying $(250 \mathrm{~L} / \mathrm{h})$ and nebulizing $(15 \mathrm{~L} / \mathrm{h})$ and the probe temperature $\left(125^{\circ} \mathrm{C}\right)$ were optimized, a tune of the source and ion optics was performed on each arylamine adduct to maximize sensitivity for each compound by monitoring the intensity of the $[\mathrm{M}+\mathrm{H}]^{+}$ion $(\mathrm{m} / \mathrm{z} 318.2$ for $\mathrm{N}$-(adenin-8-yl)benzidine adduct, $m / z 315.2$ for $\mathrm{N}$-(adenin-8-yl)-2-aminofluorene adduct, respectively) over a 2.0 to $5.0 \mathrm{kV}$ range of capillary voltages in $0.2 \mathrm{kV}$ increments. The collision energy was then optimized by monitoring the intensity of the most abundant daughter ions produced from the fragmentation of each arylamine adduct parent ion. In the collision energy optimization step, the first quadrupole (Q1) of the mass spectrometer was set to pass only the parent ion of each specific adduct or its deuterated analog. Collisions were induced in the second quadrupole region $(\mathrm{Q} 2)$ with a gas cell pressure of $\sim 2.5 \times 10^{-3}$ mbar argon (99.999\% pure), and a full scan of daughter ion spectra were acquired by the third quadrupole (Q3). Fragmentation of the N-(adenin-8-yl)benzidine adduct was monitored over collision voltages from 0 to $125 \mathrm{~V}$, and fragmentation of the $\mathrm{N}$-(adenin-8yl)-2-aminofluorene adduct was monitored over voltages from 0 to $155 \mathrm{~V}$ as it required a higher fragmentation energy.

\section{Quantitative Analysis of DNA Adducts}

For the quantitative analysis of the aryl amine adducts a multiple reaction selected ion monitoring (SIM) method was developed for each adduct and its corresponding deuterium labeled internal standard. For the $\mathrm{N}$-(adenin-8-yl)-benzidine adduct, the transitions monitored were $\mathrm{m} / \mathrm{z} 318$ to 169 and $\mathrm{m} / \mathrm{z} 318$ to 208 , while for the deuterated analog the transitions were $\mathrm{m} / \mathrm{z} 326$ to 175 and $\mathrm{m} / \mathrm{z} 326$ to 215 . For the $\mathrm{N}$-(adenin-8-yl)-2aminofluorene adduct, the transitions monitored were $\mathrm{m} / \mathrm{z} 315$ to 166 and $\mathrm{m} / \mathrm{z} 315$ to 205, while for the deuterated analog the transitions were $\mathrm{m} / \mathrm{z} 324$ to 173 , and $m / z 324$ to 205 . A standard response ratio curve was constructed by replicate (3) analyses of $10 \mu \mathrm{L}$ injections of standard solutions containing from $0.1 \mathrm{ng} / \mu \mathrm{L}, 0.2$ 

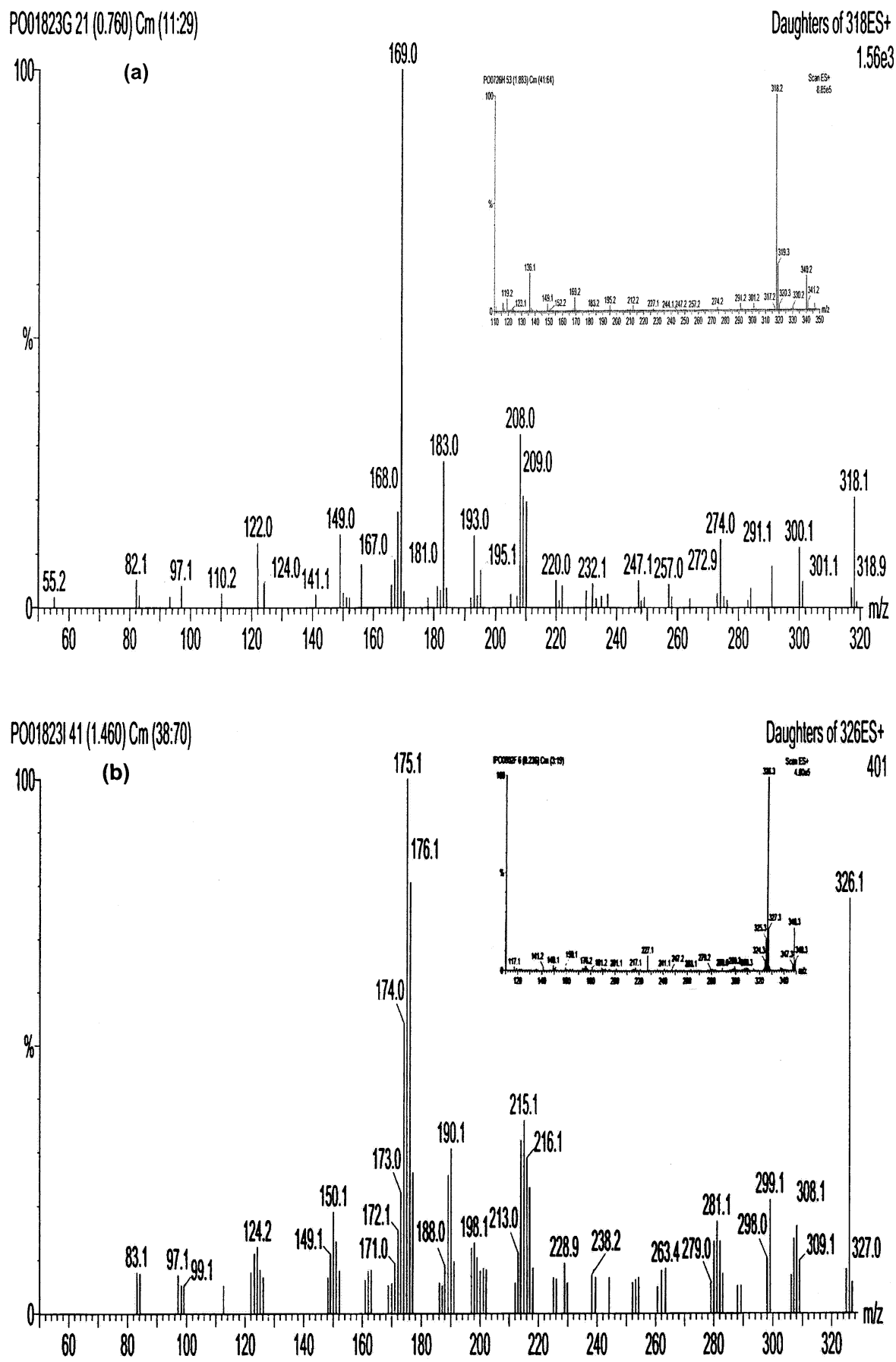

Figure 1. (a) Electrospray ionization mass spectrum of the N-(adenin-8-yl)-benzidine adduct (insert) and MS/MS daughter ion mass spectrum of the $\mathrm{N}$-(adenin-8-yl)-benzidine adduct. (b) Electrospray ionization mass spectrum of the $\mathrm{N}-\left(\mathrm{d}_{8}\right.$-adenin-8-yl)-benzidine DNA adduct (insert) and MS/MS daughter ion mass spectrum of the $\mathrm{N}-\left(\mathrm{d}_{8}\right.$-adenin-8-yl)-benzidine adduct.

$\mathrm{ng} / \mu \mathrm{L}, 0.4 \mathrm{ng} / \mu \mathrm{L}, 0.8 \mathrm{ng} / \mu \mathrm{L}, 1.6 \mathrm{ng} / \mu \mathrm{L}$, and 3.2 $\mathrm{ng} / \mu \mathrm{L}$ of adduct in DMSO. Each adduct standard also contained $0.2 \mathrm{ng} / \mu \mathrm{L}$ of the corresponding deuterated internal standard. The relative response curve was then plotted for each arylamine adduct using the most intense daughter ion (of $\mathrm{m} / \mathrm{z} 318$ to 169 versus $\mathrm{m} / \mathrm{z} 326$ to 175 ion intensities for $\mathrm{N}$-(adenin-8-yl)-benzidine and $\mathrm{m} / \mathrm{z} 315$ to 166 versus $\mathrm{m} / \mathrm{z} 324$ to 173 for $\mathrm{N}$-(adenin-8- yl)-2-aminofluorene). Blank injections both with and without internal standard and with and without salmon sperm DNA hydrolyzate were also analyzed to verify that there was no cross contamination in the ion detection windows for either compound or for non-adducted nucleotide bases in native DNA.

Two spike and recovery studies were performed to assess method validity for total DNA tissue extract 

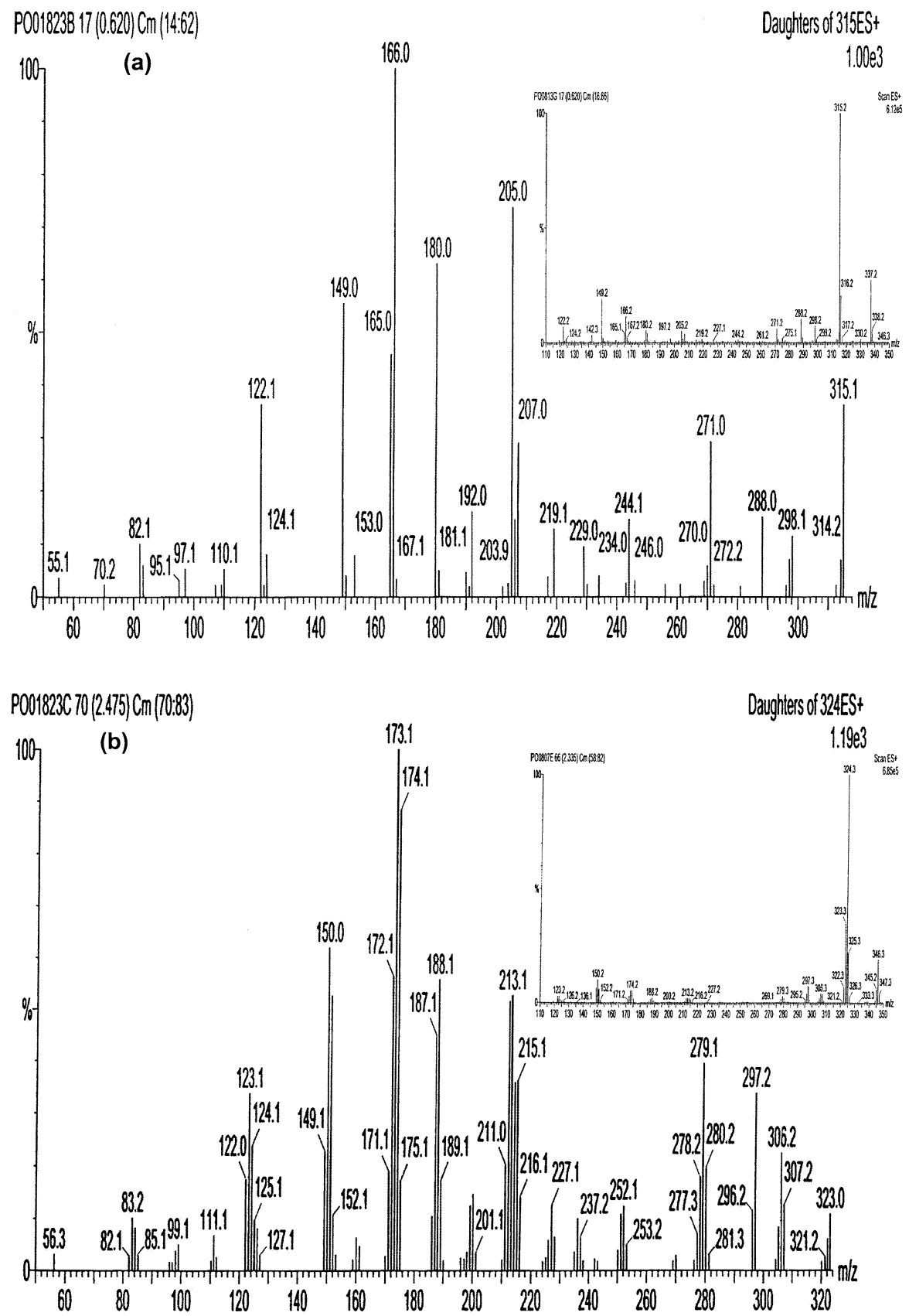

Figure 2. (a) Electrospray ionization mass spectrum of the N-(adenin-8-yl)-2-aminofluorene DNA adduct (insert) and MS/MS daughter ion mass spectrum of the $\mathrm{N}$-(adenin-8-yl)-2-aminofluorene adduct. (b) Electrospray ionization mass spectrum of the $\mathrm{N}$ - $\left(\mathrm{d}_{9}\right.$-adenin-8-yl)-2-aminofluorene - DNA adduct (insert) and MS/MS daughter ion mass spectrum of the $\mathrm{N}-\left(\mathrm{d}_{9}\right.$-adenin-8-yl)-2-aminofluorene adduct.

analysis, adduct stability, and overall procedure efficiency. Duplicate sets of samples were prepared by spiking 15, 75, 150, and $300 \mathrm{ng}$ of authentic standards into separate test tubes containing $2.5 \mathrm{~mL}$ of $0.02 \mathrm{~N} \mathrm{HCl}$. In the stability study, the solutions were then hydrolyzed for $1.5 \mathrm{~h}$ at $75^{\circ} \mathrm{C}$. After cooling, each sample was neutralized to $\mathrm{pH} 7$ with $\mathrm{NaOH}$ and then loaded on to a C18 Sep-Pak cartridge that had been precleansed and activated with $6 \mathrm{~mL}$ of acetonitrile followed by $6 \mathrm{~mL}$ of ultrapure water. Each Sep-Pak was washed with $8 \mathrm{~mL}$ of DI water and then eluted with $3 \mathrm{~mL}$ of methanol. Each methanol eluent was then evaporated to dryness under ultra-pure nitrogen and spiked with $30 \mathrm{ng}$ of the appropriate internal standard dissolved in $50 \mu \mathrm{L}$ of DMSO. The residue was then redissolved in $100 \mu \mathrm{L}$ of DMSO and analyzed by LC/MS/MS. Results were compared to standards analyzed directly by LC/MS/ MS.

In the second spike and recovery study, the authentic standards were spiked into separate test tubes contain- 


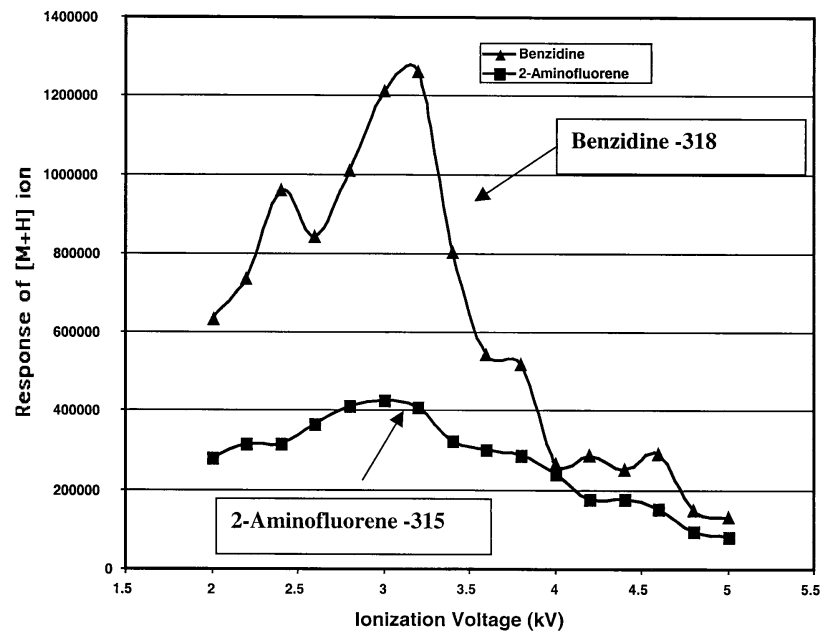

Figure 3. The optimization of the ionization voltage for $\mathrm{N}-(\mathrm{ad}-$ enin-8-yl)-benzidine adduct and N-(adenin-8-yl)-2-aminofluorene DNA adducts.

ing acid along with $4 \mathrm{mg}$ of salmon sperm DNA. Each sample was then spiked with $30 \mathrm{ng}$ of the appropriate internal standard. These solutions were then hydrolyzed for $1.0 \mathrm{~h}$ at $75^{\circ} \mathrm{C}$. After cooling, each sample was processed as above with the residue redissolved in 150 $\mu \mathrm{L}$ of DMSO and analyzed by LC/MS/MS. The results were again compared to standards analyzed directly by LC/MS/MS.

\section{Results and Discussion}

\section{Standard Characterization and Ionization Optimization}

The full-scan ESI mass spectra for the N-(adenin-8-yl)benzidine adduct, and its deuterated analog are presented in Figures 1a (insert) and b (insert), respectively. The full-scan ESI mass spectra for the N-(adenin-8-yl)-

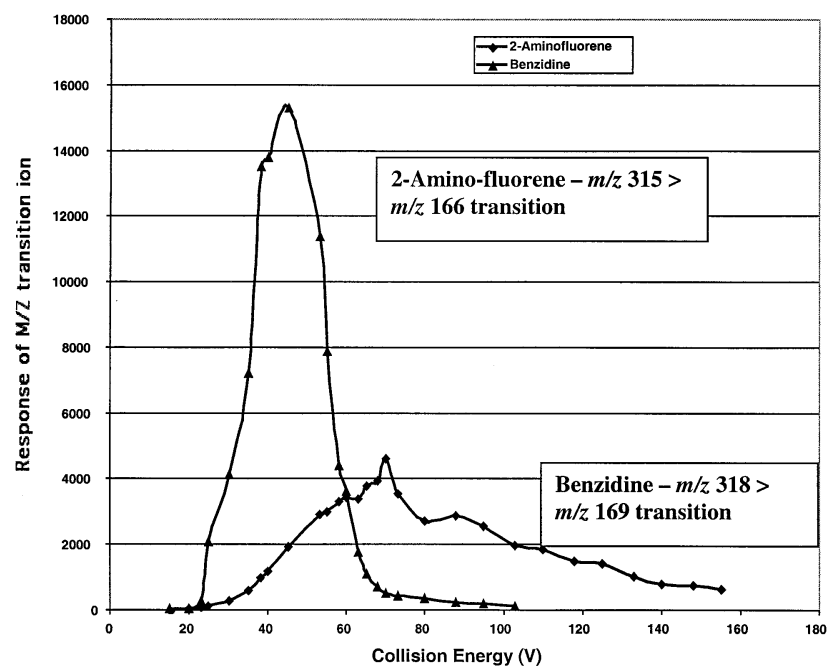

Figure 4. Optimization of collision voltages for the N-(adenin-8yl)-benzidine adduct and N-(adenin-8-yl)-2-aminoflurene DNA adducts.

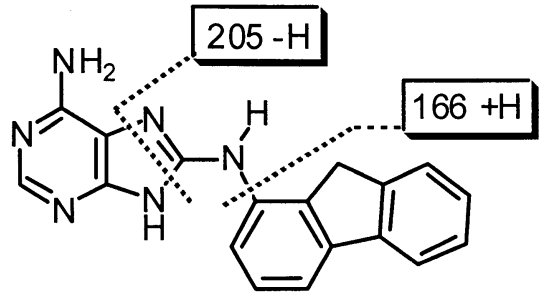

Structure 1

2-aminofluorene adduct, and its deuterated analog are shown in Figure 2a (insert) and b (insert), respectively. In all cases, the protonated $[\mathrm{M}+\mathrm{H}]^{+}$molecular ion of each adduct is clearly the most abundant ion. For $\mathrm{N}$-(adenin-8-yl)-benzidine and its deuterated analog, these were $\mathrm{m} / \mathrm{z} 318.2$ and 326.3, respectively, while for $\mathrm{N}$-(adenin-8-yl)-2-aminofluorene and its deuterated analog these were $m / z 315.2$ and 324.2. In the case of the authentic C8-adenine adducts, it was the intensity of this ion that was monitored in order to optimize ionization. In addition to the $[\mathrm{M}+\mathrm{H}]$ ions, a fairly intense sodium adduct ion was also detected in each of the parent compound adduct spectra (e.g., $\mathrm{m} / \mathrm{z} 340.2$ for the $\mathrm{N}$-(adenin-8-yl)-benzidine adduct and $\mathrm{m} / \mathrm{z} 337.2$ for $\mathrm{N}$-(adenin-8-yl)-2-aminofluorene adduct). This potential interference, which reduced sensitivity by reducing the yield of the $[\mathrm{M}+\mathrm{H}]$ ion for each compound, was subsequently minimized by use of plastic lab ware for sample preparation and storage.

In order to achieve the maximum sensitivity and selectivity, it was necessary to optimize the MS/MS conditions in order to produce the strongest signal for detection. Two parameters that were critical to be optimized were the capillary ionization voltage and the collision voltage used to induce fragmentation. The optimum ionization voltage for the $\mathrm{N}$-(adenin-8-yl)benzidine adducts was found to be $3.2 \mathrm{kV}$, and that of the $\mathrm{N}$-(adenin-8-yl)-2-aminofluorene adduct was found to be $3.0 \mathrm{kV}$. The results of the ionization study for the $\mathrm{N}$-(adenin-8-yl)-benzidine and N-(adenin-8-yl)-2-amin-

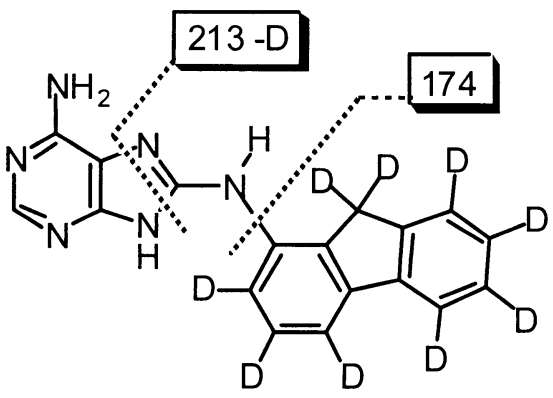

Structure 2

ofluorene adducts are shown in Figure 3. These optimum voltages were utilized in all subsequent method development steps. It is possible that at lower voltages reduced sensitivity is due to incomplete sample ioniza- 


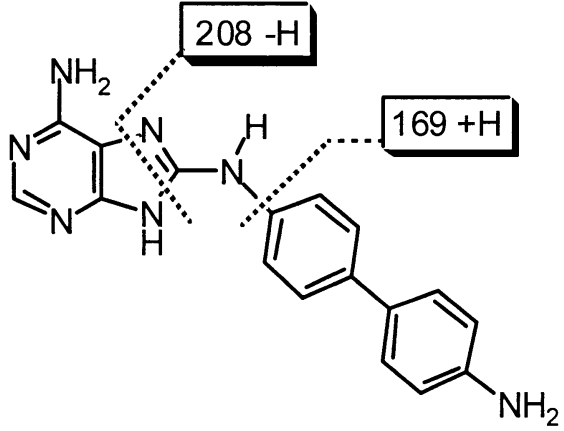

Structure 3

tion in the ESI sources of the mass spectrometer, while at higher voltages reduced sensitivity may be due to sample decomposition or the creation of multiply changed species.

In order to achieve maximum sensitivity in the MS/MS mode for each adduct and its deuterated ana$\log$, while confirmation of the identity of each adduct was retained, the transition from its molecular ion to the two most abundant characteristic daughter ions was measured using multiple reaction-selected ion monitoring. The optimum collision voltage to achieve this for the N-(adenin-8-yl)-benzidine adducts was found to be $38 \mathrm{~V}$ (Figure 4). The ESI MS/MS mass spectrum of the $\mathrm{N}$-(adenin-8-yl)-benzidine adduct and its deuterated analog at these optimized conditions are presented in Figure $1 \mathrm{a}$ and $\mathrm{b}$, respectively. Structures $\mathbf{1}$ and $\mathbf{2}$ show the key fragments selected for quantification of the authentic standard and the deuterated analog of $\mathrm{N}$ (adenin-8-yl)-benzidine.

The results of the N-(adenin-8-yl)-2-aminofluorene adduct collision energy study are presented in Figure 4 and its optimum collision voltage was found to be $70 \mathrm{~V}$. The ESI MS/MS mass spectrum of the N(adenin-8-yl)-2-aminofluorene adduct and its deuterated analog under optimized conditions are shown in Figure $2 a$ and $b$, respectively. Structures 3 and 4 show the key fragments selected for quantification of the authentic standard and the deuterated analog for

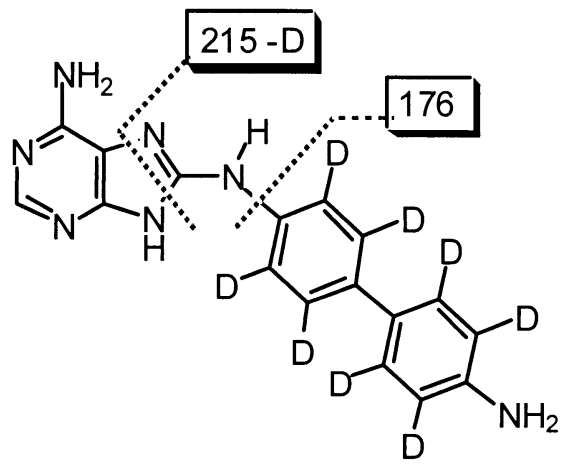

Structure 4
Table 1. N-(Adenin-8-yl)-benzidine adduct standard calibration data

\begin{tabular}{lcccc}
\hline & & \multicolumn{4}{c}{$\begin{array}{c}\text { Average } \% \\
\text { accuracy } \\
\pm\end{array}$} \\
$\begin{array}{l}\text { Ng adduct } \\
\text { on } \\
\text { column }\end{array}$ & $\begin{array}{c}\text { Ng adduct } \\
\text { calculated }\end{array}$ & $\begin{array}{c}\% \\
\text { Accuracy }\end{array}$ & $\begin{array}{c}\text { standard } \\
\text { deviation }\end{array}$ & $\begin{array}{c}\% \\
\text { RSD }\end{array}$ \\
\hline \hline 1.00 & 1.11 & 111 & & \\
1.00 & 1.10 & 110 & $110 \pm 1.2$ & 1.10 \\
1.00 & 1.08 & 108 & & \\
2.00 & 2.01 & 100 & & \\
2.00 & 2.03 & 102 & $105 \pm 6.6$ & 6.33 \\
2.00 & 2.24 & 112 & & \\
4.00 & 3.83 & 96 & & \\
4.00 & 4.29 & 107 & $102 \pm 5.8$ & 5.71 \\
4.00 & 4.10 & 102 & & \\
8.00 & 8.01 & 100 & & \\
8.00 & 8.15 & 102 & $101 \pm 1.0$ & 1.03 \\
8.00 & 8.16 & 102 & & \\
16.00 & 14.92 & 93 & & \\
16.00 & 14.67 & 92 & $93 \pm 1.7$ & 1.85 \\
16.00 & 15.22 & 95 & & \\
32.00 & 32.04 & 100 & & \\
32.00 & 32.62 & 102 & $101 \pm 1.3$ & 1.24 \\
32.00 & 32.82 & 103 & & \\
\hline & & & & \\
\hline
\end{tabular}

2-aminofluoroene. The relatively large difference in the collision energy required for fragmentation of N-(adenin-8-yl)-benzidine versus N-(adenin-8-yl)-2aminofluorene adducts may be the result of stabilization of the electron distribution in the extended ring structure of the $\mathrm{N}$-(adenin-8-yl)-2-aminofluorene

Table 2. N-(adenin-8-yl)-2-aminofluorene adduct standard calibration data

\begin{tabular}{|c|c|c|c|c|}
\hline $\begin{array}{l}\mathrm{Ng} \text { adduct } \\
\text { on } \\
\text { column }\end{array}$ & $\begin{array}{l}\mathrm{Ng} \text { adduct } \\
\text { calculated }\end{array}$ & $\begin{array}{c}\% \\
\text { Accuracy }\end{array}$ & $\begin{array}{c}\text { Average \% } \\
\text { accuracy } \\
\pm \\
\text { standard } \\
\text { deviation }\end{array}$ & $\begin{array}{c}\% \\
\text { RSD }\end{array}$ \\
\hline 1.00 & 0.93 & 93 & & \\
\hline 1.00 & 0.89 & 89 & $93 \pm 4.2$ & 4.49 \\
\hline 1.00 & 0.97 & 97 & & \\
\hline 2.00 & 2.13 & 106 & & \\
\hline 2.00 & 1.89 & 95 & $102 \pm 6.2$ & 6.06 \\
\hline 2.00 & 2.08 & 104 & & \\
\hline 4.00 & 4.18 & 105 & & \\
\hline 4.00 & 3.91 & 98 & $101 \pm 3.5$ & 3.46 \\
\hline 4.00 & 4.01 & 100 & & \\
\hline 8.00 & 8.52 & 106 & & \\
\hline 8.00 & 8.35 & 104 & $106 \pm 1.1$ & 1.04 \\
\hline 8.00 & 8.45 & 106 & & \\
\hline 16.00 & 16.42 & 103 & & \\
\hline 16.00 & 16.35 & 102 & $100 \pm 3.5$ & 3.45 \\
\hline 16.00 & 15.22 & 95 & & \\
\hline 32.00 & 31.36 & 98 & & \\
\hline 32.00 & 31.89 & 100 & $100 \pm 1.5$ & 1.49 \\
\hline 32.00 & 32.31 & 101 & & \\
\hline
\end{tabular}


Table 3. Stability during thermal hydrolysis of the $\mathrm{N}$-(Adenin-8-yl)-benzidine adduct

\begin{tabular}{lccc}
\hline $\begin{array}{l}\text { Ng Benzidine } \\
\text { Adduct Spike }\end{array}$ & $\begin{array}{c}\text { Ng Benzidine } \\
\text { Adduct } \\
\text { Calculated }\end{array}$ & $\begin{array}{c}\text { Recovery } \\
(\%)\end{array}$ & $\begin{array}{c}\text { Average } \\
\text { Recovery }\end{array}$ \\
\hline \hline 1.00 & 0.90 & 90 & 91 \\
1.00 & 0.91 & 91 & \\
5.00 & 4.69 & 94 & 93 \\
5.00 & 4.58 & 92 & \\
10.00 & 9.21 & 92 & 91 \\
10.00 & 8.98 & 90 & \\
20.00 & 18.21 & 91 & 92 \\
20.00 & 18.44 & 92 & \\
\hline
\end{tabular}

adduct compared with that of the single aromatic ring in the $\mathrm{N}$-(adenin-8-yl)-benzidine adduct.

\section{Quantitative LC/MS/MS Detection Method}

A calibration curve was prepared from triplicate runs of authentic standard solutions over a range of 1 to $32 \mathrm{ng}$ $(1,2,4,8,16$, and $32 \mathrm{ng})$ of adduct on-column. Each standard injection also contained a fixed quantity ( $2 \mathrm{ng}$ on column) of deuterated internal standard. The peak height rather than its area was used for quantification as more precise results were obtained in this mode and fewer matrix interferences were observed in tissue DNA samples.

The data used to construct the standard curve for the $\mathrm{N}$-(adenin-8-yl)-benzidine adducts is presented in Table 1. A linear response ratio versus concentration was determined ( $\mathrm{y}=0.8324 \mathrm{x}-0.1728)$ using the method of least squares with a resulting $R^{2}$ of 0.9981 . The overall accuracy for all concentrations tested ranged from 92 to $112 \%$, with the percent relative standard deviation ranging from 1.1 to $6.33 \%$. The limit of detection was calculated after repeated injections of $30 \mathrm{pg}$ on-column to be $22 \mathrm{pg}$ (69 fmole) (signal-to-noise $(\mathrm{S} / \mathrm{N})=3$ ) and the limit of quantification was $73 \mathrm{pg}(230 \mathrm{fmole})(\mathrm{S} / \mathrm{N}=$ 10) [27]. The data used to construct the standard curve for the N-(adenin-8-yl)-2-aminofluorene adducts is presented in Table 2. A linear response ratio versus con-

Table 4. Stability during thermal hydrolysis of the $\mathrm{N}$-(adenin-8-yl)-2-aminofluorene adduct

\begin{tabular}{|c|c|c|c|}
\hline $\begin{array}{l}\mathrm{Ng} \text { 2-Amino- } \\
\text { fluorene } \\
\text { Adduct } \\
\text { Spike }\end{array}$ & $\begin{array}{l}\text { Ng 2-Amino- } \\
\text { fluorene } \\
\text { Adduct } \\
\text { Calculated }\end{array}$ & $\begin{array}{c}\text { Recovery } \\
(\%)\end{array}$ & $\begin{array}{l}\text { Average } \\
\text { Recovery }\end{array}$ \\
\hline $\begin{array}{l}1.00 \\
1.00\end{array}$ & $\begin{array}{l}0.96 \\
0.97\end{array}$ & $\begin{array}{l}96 \\
97\end{array}$ & 97 \\
\hline $\begin{array}{l}5.00 \\
5.00\end{array}$ & $\begin{array}{l}4.75 \\
4.81\end{array}$ & $\begin{array}{l}95 \\
96\end{array}$ & 96 \\
\hline $\begin{array}{l}10.00 \\
10.00\end{array}$ & $\begin{array}{l}9.69 \\
9.48\end{array}$ & $\begin{array}{l}97 \\
95\end{array}$ & 96 \\
\hline $\begin{array}{l}20.00 \\
20.00\end{array}$ & $\begin{array}{l}19.24 \\
19.07\end{array}$ & $\begin{array}{l}96 \\
95\end{array}$ & 96 \\
\hline
\end{tabular}

Table 5. Recovery study of the N-(Adenin-8-yl)-benzidine adduct from salmon DNA matrix

\begin{tabular}{lccc}
\hline $\begin{array}{l}\text { Ng Benzidine } \\
\text { Adduct Spike }\end{array}$ & $\begin{array}{c}\text { Ng Benzidine } \\
\text { Adduct } \\
\text { Calculated }\end{array}$ & $\begin{array}{c}\text { Recovery } \\
(\%)\end{array}$ & $\begin{array}{r}\text { Average } \\
\text { Recovery }\end{array}$ \\
\hline \hline 1.00 & 0.96 & 96 & 98 \\
1.00 & 0.99 & 99 & \\
5.00 & 5.31 & 106 & 108 \\
5.00 & 5.49 & 110 & \\
10.00 & 10.18 & 102 & 108 \\
10.00 & 11.43 & 114 & \\
20.00 & 21.36 & 107 & 106 \\
20.00 & 20.95 & 105 & \\
\hline
\end{tabular}

centration was determined $(\mathrm{y}=0.5449 \mathrm{x}+0.1454)$ using the method of least squares with a resulting $R^{2}$ of 0.9996. The overall accuracy for all standards tested ranged from 89 to $106 \%$, with the percent relative standard deviation ranging from 1.04 to $6.06 \%$. The limit of detection was calculated after repeated injections of $60 \mathrm{pg}$ on-column to be $51 \mathrm{pg}$ (162 fmole) $(\mathrm{S} / \mathrm{N}$ $=3$ ) and the limit of quantification was $171 \mathrm{pg}$ (543 fmole) $(\mathrm{S} / \mathrm{N}=10)$.

\section{Spike and Recovery Studies}

In order to demonstrate the method validity, analyses of total DNA extracts from tissue (salmon sperm), adduct stability to acid hydrolysis and sample preparation steps, and overall procedural recovery efficiency were measured. The first study determined the adduct standards and deuterated standards stability to the thermal acid hydrolysis conditions which exceeded those typically used in the preparation of DNA hydrolysates from tissue samples (salmon sperm) and the efficiency of recovery during the Sep-Pak C18 cartridge clean-up step. The recovery of the N-(adenin-8-yl)benzidine adduct spike varied slightly ranging from $90-94 \%$ recovery, with an average of $92 \%$ (Table 3 ). The recovery of the $\mathrm{N}$-(adenin-8-yl)-2-aminofluorene adduct spike also varied slightly ranging from $95-97 \%$ recovery, with an average of $96 \%$ (Table 4). These data

Table 6. Recovery study of the N-(adenin-8-yl)2-aminofluorene adduct from salmon DNA

\begin{tabular}{|c|c|c|c|}
\hline $\begin{array}{l}\mathrm{Ng} \text { 2-Amino- } \\
\text { fluorene } \\
\text { Adduct } \\
\text { Spike }\end{array}$ & $\begin{array}{l}\text { Ng 2-Amino- } \\
\text { fluorene } \\
\text { Adduct } \\
\text { Calculated }\end{array}$ & $\begin{array}{c}\text { Recovery } \\
\text { (\%) }\end{array}$ & $\begin{array}{l}\text { Average } \\
\text { Recovery }\end{array}$ \\
\hline $\begin{array}{l}1.00 \\
1.00\end{array}$ & $\begin{array}{l}0.95 \\
0.99\end{array}$ & $\begin{array}{l}95 \\
99\end{array}$ & 97 \\
\hline $\begin{array}{l}5.00 \\
5.00\end{array}$ & $\begin{array}{l}5.71 \\
5.09\end{array}$ & $\begin{array}{l}114 \\
102\end{array}$ & 108 \\
\hline $\begin{array}{l}10.00 \\
10.00\end{array}$ & $\begin{array}{l}11.65 \\
10.31\end{array}$ & $\begin{array}{l}117 \\
103\end{array}$ & 110 \\
\hline $\begin{array}{l}20.00 \\
20.00\end{array}$ & $\begin{array}{l}20.06 \\
21.86\end{array}$ & $\begin{array}{l}100 \\
109\end{array}$ & 105 \\
\hline
\end{tabular}



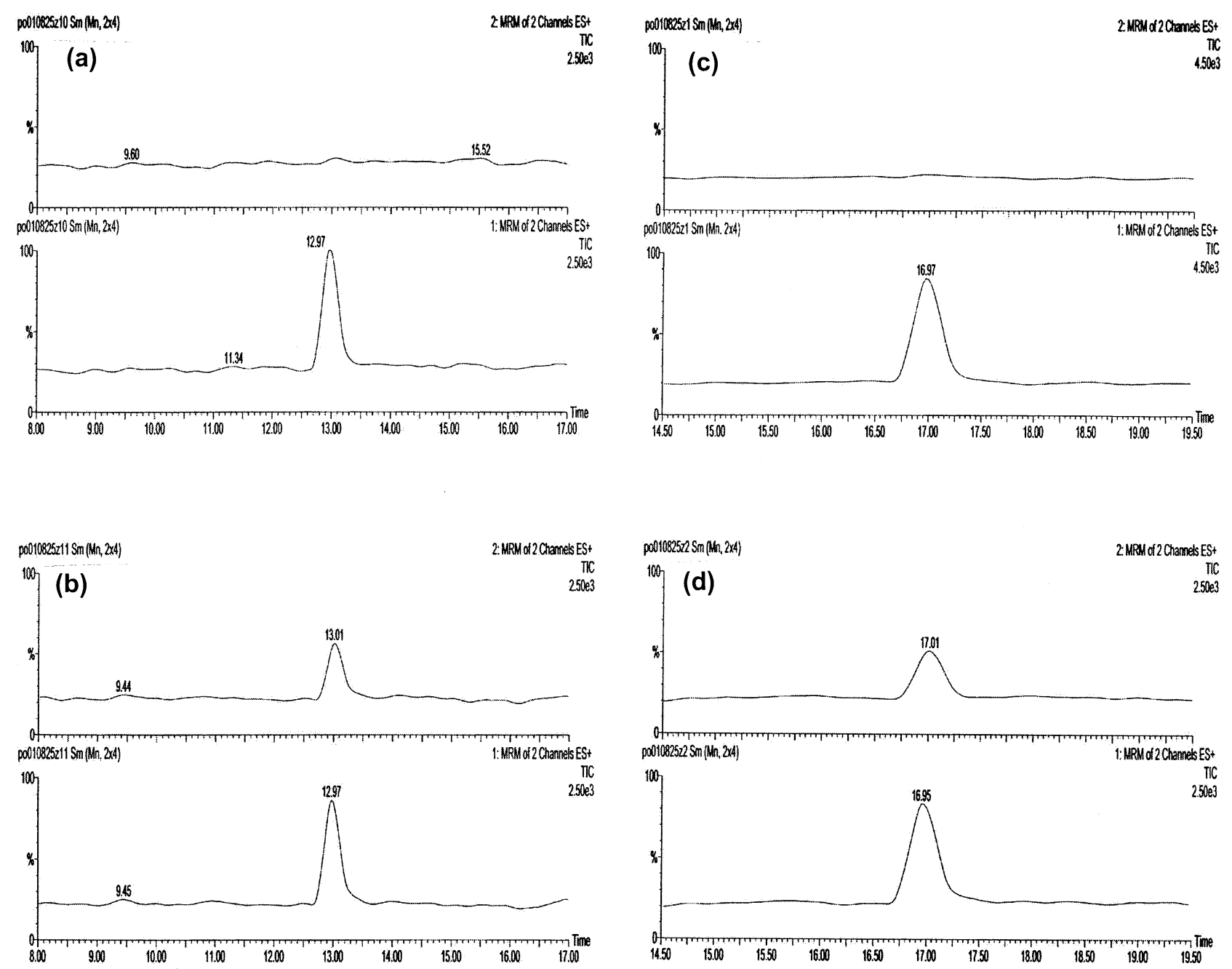

Figure 5. Representative mass chromatograms for the salmon sperm blank and spike/recovery samples. In each pair, the top chromatogram is the authentic spike response and the bottom chromatogram is the internal standard response. (a)Benzidine adducts salmon sperm DNA blank, (b) 1 ng N-(adenin-8-yl)-benzidine adduct spike, (c) 2-aminofluorene salmon sperm DNA blank, (d) 1 ng $\mathrm{N}$-(adenin-8-yl)-2-aminofluorene spike

indicate that there is a small loss in recovery due to either the acid hydrolysis of the sample or the Sep-Pak concentration step. This loss is relatively small (3-10\%) and appears to be very consistent. It was subsequently shown that the losses here were due to small amounts of adduct standards retained on the Sep-Pack at low concentrations rather than thermal hydrolysis losses. These losses were not observed when larger amounts of total DNA hydrolyzates were passed through the SepPacks as is observed in the next set of results.

The second spike and recovery study demonstrated the effect of a biological matrix, in this case the salmon tissue total DNA extract matrix, upon adduct recovery, method accuracy and precision, and also determined if any natural matrix interferences were present which could bias results. The results for the total DNA extract (salmon sperm tissue) spike and recovery experiment were slightly improved over the stability/efficiency study (Tables 5 and 6). Average recoveries were some- what higher but were slightly more variable. The recovery of the N-(adenin-8-yl)-benzidine adduct in the tissue DNA samples ranged from $96-114 \%$ recovery, with an average of $105 \%$ while the recovery of the N-(adenin8-yl)-2-aminofluorene adduct in the tissue DNA samples ranged from $95-117 \%$ recovery with an average recovery of $105 \%$.

This improved recovery observed is most likely due to one primary factor. Since the internal standards underwent the entire sample preparation procedure along with the non-labeled authentic adduct spike, any material that was lost would be proportional to the amount of the internal standard also lost thus making it possible to correct for these errors. Because the recovery was over $100 \%$ in some cases it is also likely that the larger amounts of total nucleotides being handled reduced non-specific binding of analytes to lab ware.

Representative chromatograms of tissue DNA blank 
and $1 \mathrm{ng}$ adduct spikes in DNA samples are presented in Figure 5.

Tandem mass spectrometry has been utilized to identify and quantify the $\mathrm{N}$-acetylamino metabolite adducts of both 2-aminofluorene and benzidine. Lakshmi and coworkers $[28,29]$ utilized an ESI tandem mass spectral method for analysis of N-acetylaminobenzidine guanine adducts to confirm the identity of adducts detected through P32-postlabelling but not for quantitative analysis. Wolf and Vouros [30, 31] developed a capillary electrophoresis tandem mass spectrometric method for quantification of N-acetyl aminofluorene N2- and C8-guanine adducts formed in vitro with calf thymus DNA. They reported detection limits for these adducts in the range of 50 fmole on-column. Thus, the potential for quantification of this and other classes of bulky DNA adduct-forming compounds using LC/MS/MS methods seems great. This paper is the first report of quantification of the non-acetylated adducts of these two amines with adenine.

\section{Conclusion}

In conclusion, a sensitive, selective method for the detection of N-(adenin-8-yl)-benzidine and $\mathrm{N}$-(adenin8-yl)-2-aminofluorene-C8-adenine adducts in DNA was developed. The average limit of detection was $\sim 100$ fmole which would correspond to one adduct detected in $\sim 6 \times 10^{7}$ bases from a $4 \mathrm{mg}$ DNA sample, which is well within physiologically and toxicologically relevant levels. The sample preparation and analysis procedure yielded an average overall recovery of $105 \%$. Injection of volumes of extracted DNA hydrolyzates greater than $10 \mu \mathrm{L}$ (e.g., $20-50 \mu \mathrm{L}$ ) could yield even lower detection limits but could incur added interferences from matrix effects.

This method is applicable for quantifying $\mathrm{N}$-(adenin8-yl)-benzidine adducts and N-(adenin-8-yl)-2-aminofluorene from in vitro and in vivo studies. It is currently being utilized to correlate arylamine exposures to adduct formation frequencies, and to investigate the kinetics of adduct formation and repair. The method could also be used as a diagnostic method to screen for DNA damage in environmental and industrial settings where these compounds are present. By slightly changing the multiple reaction selected ion monitoring parameters in the mass spectrometer, this method could be modified to detect other arylamine adduct isomers, though quantification would not be as precise without the use of synthesized authentic isomer standards. This analytical method has numerous applications for future studies in this field.

\section{Acknowledgments}

This work was supported by the U.S. Department of Energy through an EPSCoR grant and by the U.S. Environmental Protection Agency grant no. (XP-97528301-0) to JCM.

\section{References}

1. Later, D. W. Handbook of Polycyclic Aromatic Hydrocarbons; Marcel Decker, Inc.: New York, 1985, 265-290.

2. Neilson, A. H. The Handbook of Environmental Chemistry, Volume 3: Anthropogenic Compounds, Part J: PAHs and Related Compounds: Biology; Lewis Publishers; Boca Raton, FL, 1997, pp 346-504.

3. Neilson, A. H., ed. The Handbook of Environmental Chemistry, Volume 3: Anthropogenic Compounds, Part I: PAHs and Related Compounds: Chemistry; Lewis Publishers; Boca Raton, FL, 1997, pp 300-345.

4. Choudhary, G.; Goldhaber, S. Toxicological Profile for Benzidine (update, August 1995), Research Triangle Institue; Research Triangle Park: NC, 1995; p 192.

5. Toxicological Profile for Benzidine. Clement Associates, Inc.: Fairfax, VA, 1989; p 117.

6. Integrated Risk Information System (IRIS) on Benzidine. USEPA, Environmental Criteria and Assessment Office, Office of Health and Environmental Assessment, Office of Research and Development: Cincinnati, OH, 1993.

7. Devanesan, P.; Ariese, F.; Jankowiak, R.; Small, G. J.; Rogan, E. G.; Cavalieri, E. L. Preparation, Isolation, and Characterization of Dibenzo[a,l]Pyrene Diol Epoxide-Deoxyribonucleoside Monophosphate Adducts by HPLC and Fluorescence LineNarrowing Spectroscopy. Chem. Res. Toxicol. 1999, 12, 789-795.

8. Mathieu, A.; Payne, J. F.; Fancey, L. L.; Santella, R. M.; Young, T. L. Polycyclic Aromatic Hydrocarbon DNA Adducts in Beluga Whales from the Arctic. J. Toxicol. Environ. Health 1997, $51,1-4$.

9. Scherer, G.; Richter, E. Biomonitoring Exposure to Environmental Tobacco Smoke (ETS): A critical Reappraisal. Hum. Exp. Toxicol. 1997, 16, 449-459.

10. Seed, J. L.; Kensler, T. W.; Elia, M.; Trush, M. A. Induction of Sister-Chromatid Exchanges by Polycyclic Aromatic-Hydrocarbons Following Metabolic-Activation with Phorbol EsterStimulated Human Polymorphonuclear Leukocytes. Res. Commun. Chem. Pathol. Pharmacol. 1990, 67, 349-360.

11. Brudzewski, J.; Shusterman, D.; Becker, C.; Borak, J.; Cannella, J.; Goldstein, B.; Hall, A.; Jackson, R. J.; Rodnick, J.; Wheater, R.; Wummer, B. Polycyclic Aromatic Hydrocarbon Toxicity. Am. Fam. Phys. 1993, 47, 623-628.

12. Autrup, H.; Vestergaard, A. B.; Okkels, H. Transplacental Transfer of Environmental Genotoxins-Polycyclic Aromatic Hydrocarbon-Albumin in Nonsmoking Women, and the Effect of Maternal Gstm1 Genotype. Carcinogenesis 1995, 16, 1305-1309.

13. Autrup, H.; Vestergaard, A. B. Transplacental Transfer of Environmental Genotoxins-Polycyclic Aromatic Hydrocarbon-Albumin in Nonsmoking Women. Environ. Health Persp. 1996, 104, 625-627.

14. Matikainen, T.; Perez, G. I.; Jurisicova, A.; Pru, J. K.; Schlezinger, J. J.; Ryu, H. Y.; Laine, J.; Sakai, T.; Korsmeyer, S. J.; Casper, R. F.; Sherr, D. H.; Tilly, J. L. Aromatic Hydrocarbon Receptor-Driven Bax Gene Expression is Required for Premature Ovarian Failure Caused by Biohazardous Environmental Chemicals. Nature Genet. 2001, 28, 355-360.

15. Bolognesi, C.; Cesarone, C. F.; Santi, L. DNA Damage and Repair Induced in Vivo by Benzidine Treatment. BollettinoSocieta Ital. Biol. Speriment. 1980, 56, 1673-1679.

16. Cihak, R. Evaluation of Benzidine by the Micronucleus Test. Mutat. Res. 1979, 67, 383-384.

17. Kennelly, J. C.; Clare, C. B.; Campbell, J.; Lane, M. P.; Harrington, D. H.; Cole, H.; Garner, R. C. The Mutagenic Activity of Ethylmethanesulfonate, Benzidine, and Benzo[a]Pyrene at the Hprt Locus of Wild-Type L5178y Mouse Lymphoma-Cells. Mutagenesis 1990, 5, 21-26. 
18. Heflich, R. H.; Neft, R. E. Genetic Toxicity of 2-Acetylaminofluorene, 2-Aminofluorene and Some of Their Metabolites and Model Metabolites. Mutat. Res. Rev. Genet. Toxicol. 1994, 318, 73-174.

19. Krauss, R. S.; Angermanstewart, J.; Eling, T. E.; Dooley, K. L.; Kadlubar, F. F. The Formation of 2-Aminofluorene-DNA Adducts Invivo-Evidence for Peroxidase-Mediated Activation. J. Biochem. Toxicol. 1989, 4, 111-117.

20. Berberian, R. M.; Eurich, G. E.; Rios, G. A.; Harris, C. Formation of Glutathione Adducts and 2-Aminofluorene from 2-Nitrosofluorene in Postimplantation Rat Conceptuses in Vitro. Reproduct. Toxicol. 1996, 10, 273-284.

21. Imamura, A.; Tani, S.; Taketoshi, M.; Danzuka, T. The Relation Between Ames Test Data and Electronic-Structure for a Series of Benzidine Derivatives Investigated by Using Cluster-Analysis. Japan J. Cancer Res. 1985, 76, 937-945.

22. Huang, H.; Jemal, A.; David, C.; Barker, S. A.; Swenson, D. H.; Means, J. C. Analysis of DNA Adduct, S- 2-(N-7-Guanyl)Ethyl Glutathione by Liquid Chromatography Mass Spectrometry and Liquid Chromatography Tandem Mass Spectrometry. Anal. Biochem. 1998, 265, 139-150.

23. Bjoerseth, A.; Ramdahl, T. Handbook of Polycyclic Aromatic Hydrocarbons, Vol. II: Emission Sources and Recent Progress in Analytical Chemistry; Marcel Dekker: New York, 1985, pp 125-221.

24. Josephy, P. D. Molecular Toxicology. Oxford University Press: Oxford and New York, 1997, pp 261-280.
25. Beland, F. A.; Kadlubar, F. F. Formation and Persistence of Arylamine DNA Adducts In Vivo. Environ. Health Perspect. $1985,62,19-30$.

26. Schoffers, E.; Olsen, P. D.; Means, J. C. Synthesis of C8Adenosine Adducts of Arylamines Using Palladium Catalysis. Org. Lett. 2001, 3, 4221-4223.

27. Taylor, J. K. Quality Assurance of Chemical Measurements; Lewis Publishers Inc.: Chelsea, MI, 1987, pp 75-92.

28. Lakshmi, V. M.; Hsu, F. F.; Davis, B. B.; Zenser, T. V. N-Acetylbenzidine-DNA Adduct Formation by Phorbol 12Myristate-Stimulated Human Polymorphonuclear Neutrophils. Chem. Res. Toxicol. 2000, 13, 785-792.

29. Lakshmi, V. M.; Hsu, F. F.; McGarry, A. E.; Davis, B. B.; Zenser, T. V. Hypochlorous Acid-Mediated Activation of $\mathrm{N}$-Acetylbenzidine to form $\mathrm{N}^{\prime}$-(3'-Monophospho-Deoxyguanosin-8-yl)-N-Acetylbenzidine. Toxicol. Sci. 2000, 53, 202 212.

30. Wolf, S. M.; Vouros, P. Incorporation of Sample Stacking Techniques into the Capillary Electrophoresis Cf-Fab MassSpectrometric Analysis of DNA Adducts. Anal. Chem. 1995, 67, 891-900.

31. Wolf, S. M.; Vouros, P. Application of Capillary LiquidChromatography Coupled with Tandem Mass-Spectrometric Methods to the Rapid Screening of Adducts Formed by the Reaction of N-Acetoxy-N-Acetyl-2- Aminofluorene with Calf Thymus DNA. Chem. Res. Toxicol. 1994, 7, 82-88. 